UDC 821.163.41-14.09 Milutinović S.

UDC 821.163.41-14.09 Hadžić J.

UDC 821.163.41-14.09"18"

https://doi.org/10.18485/ms zmsi.2021.104.4

ОРИГИНАЛНИ НАУЧНЙ РАД

\author{
СТАНИША ВОЈИНОВИЋ \\ Београд, Србија \\ Е-адреса: stanisavojinovic@eunet.rs
}

\title{
ПОЕЗИЈА УСТАВОБРАНИТЕЉСКОГ ПЕРИОДА
}

САЖЕТАК: У раду је анализирана поезија уставобранитеља и њихових противника, која представља почетак вишестраначког живота у Србији и почетак политичке (династичке) поезије. Посебно су истакнута тројица песника Сима Милутиновић, Јован Хаџић и Ђорђе Гроздановић, а поменути су и поједини заборављени, као што су Ђорђе Малетић, Татомир Миловук и др.

КљУЧНЕ РЕЧИ: династичке борбе, Сима Милутиновић, Јован Хаџић, Тома Вучић Перишић, Аврам Петронијевић, Турска, песници, удвориштво

\section{УВОД}

У време уставобранитељске кризе појавило се више посебних издања у прози и стиховима, са изразито политичким ставовима, а у служби династије Обреновић или Карађорђевић. То време је почетак вишестраначког система и ангажоване (политичке, удворичке) поезије код нас.

Почетак страначког живота у Србији везује се за крај прве владе Милоша Обреновића. Устав из 1838. предвидео је Савет, састављен од 17 доживотних чланова, који је контролисао кнежеву власт. Положај кнеза Милоша постао је неодржив и он је абдицирао 1/13. јуна 1839. Како је кнез Милан био болестан, образовано је намесништво у којем су се налазили Аврам Петронијевић, Јеврем Обреновић и Тома Вучић Перишић. После смрти кнеза Милана за кнеза је изабран Михаило. Оклевање кнеза Милоша да дозволи кнезу Михаилу долазак у земљу уставобранитељи су искористили да почну агитацију за повратак Карађорђевића на престо. Образована је комисија која је, под видом тумачења устава народу, у ствари тајно агитовала за Карађорђевиће.

Доласком кнеза Михаила у Србију у марту 1840. године ситуација се погоршала. Опозиција се ујединила и изградила платформу за ограничење његове власти. Кнез Михаило и обреновићевци, са друге стране, приморали су уставобранитеље да одступе са својих државних звања. Уставобранитељи су се осетили угрожено, па су прешли у београдску тврђаву и ставили се 
под заштиту Турске. Порта је послала свога изасланика Муса-ефендију, који је стигао у Београд 28. јуна / 10. јула 1840 . Сазвана је и Народна скупштина, која је почела рад на Илиндан 22. јула / 1. августа 1840 . У раду скупштине због личне безбедности нису присуствовали Вучић, Петронијевић и Стојан Симић. Скупштина је поднела тужбе Муса-ефендији 4. августа 1840. у којој су за тешко стање у Србији оптужени водећи уставобранитељи, а за предводника опозиције је означен Тома Вучић Перишић. Због тога су уставобранитељи названи и вучићевци. Оптужбе су биле тешке, па су кнез Михаило и влада 12. августа формирали „Чрезвичајну комисију”, која ће судити уставобранитељима.

Како криза није могла бити решена мирним путем, изасланик Турске Муса-ефендија је 16/28. октобра 1840, са својом свитом и 37 Срба уставобранитеља, напустио Београд и преко Видина отпутовао у Цариград.

У Видину је остао највећи број изгнаних а у Цариград су отишли Тома Вучић Перишић, Аврам Петронијевић и Милутин Гарашанин. Незадовољство народа је стишано, мере кнеза Михаила су биле усмерене ка ублажавању стања у земљи. Извршене су и извесне реформе, али је дошло до повећања пореза са 5 на 6 талира. Заузимањем Порте, Аустрије и Русије крајем 1841. уставобранитељи су се вратили у земљу.

Повратком уставобранитеља Порта и Аустрија су покушале да приволе кнеза Михаила да у своју владу узме Вучића и Петронијевића. Михаило није пристао и дошло је до новог заоштравања стања у Србији. Порта је ради смиривања ситуације послала у Србију новог изасланика, Шекиб-ефендију, који је приспео у Београд 13/25. августа 1842. Како рад изасланика и посредовање руског конзула нису помирили сукобљене стране, уставобранитељи су одлучили да подигну народ на буну против кнеза Михаила.

Припремљен је и терен у земљи и иностранству. Вучић је преузео главну улогу у извођењу буне. План је био да пре кнеза Михаила стигне у Крагујевац и преузме војску и наоружање, што је и учинио. Уследила је и акција кнеза Михаила, који је са војском стигао надомак Крагујевца. Неодлучност кнеза Михаила, „да се не пролива братска крв”, али и буне уставобранитеља у осталим окрузима, омогућили су победу уставобранитеља. Одлучујући сукоб одиграо се код Жабара, у зору 25. августа / 6. септембра. Вучићеве присталице почеле су тући из „картаче” војску кнеза Михаила.

Тиме су присталице Обреновића деморалисане, кнез Михаило је распустио народ и праћен својом свитом кренуо према Београду. Вучић га је пратио, а када је чуо да је са својим присталицама прешао у Аустрију, дошао je 26. августа / 7. септембра са војском на Врачар. Убрзо су у Вучићев логор дошли и остали уставобранитељи, на челу са Аврамом Петронијевићем. Ту је договорено да се 2/14. септембра 1842. одржи народна скупштина за избор кнеза, а да Србијом управља „ново правитељство” које сачињавају Аврам Петронијевић као председник привремене владе и Тома Вучић Перишић као „предводитељ” народа.

Уговореног дана одржана је скупштина и за кнеза је изабран Александар Карађорђевић. Порта је признала новог кнеза. На Народној скупштини, одржаној 26. октобра / 7. новембра 1842, прочитан је султанов берат, а кнез Александар је заузео своје место. Истог дана донети су укази о првим поста- 
вљењима, којима је кнез Александар Карађорђевић поставио Аврама Петронијевића за кнежевог представника и попечитеља иностраних дела, а Тому Вучића Перишића за министра унутрашњих дела.

Под притиском Русије дошло је до другог избора Александра Карађорђевића за кнеза, 15/27. јуна 1843.

Долазак уставобранитеља на власт очекиван је у народу као долазак нечега новог, прогресивног, просперитетног за Србију. У суштини, било је другачије. Бирократски систем кнеза Михаила је додатно развијен. Кнез Александар је делио врховну управу са Државним саветом, а чиновништво је било независно од њега. Године 1858. дошло је до нове промене династије на власти, до друге владе кнеза Милоша и владе кнеза Михаила. Модерна европска администрација, коју су створили уставобранитељи, опстала је и после повратка Обреновића на престо. Кнез Михаило је успео утолико да концентрише власт у својим рукама. Временом концепт бирократског деспотизма уступао је место другим системима, али се нешто од њега задржало све до Другог светског рата. ${ }^{1}$

\section{ЗНАЧАЈНИ ПЕСНИЦИ}

По настанку уставобранитељске опозиције почело је стварање политичке поезије код нас. Песници су се поделили на обреновићевце и уставобранитеље. О овој поезији први је опширно писао Јаша М. Продановић. ${ }^{2}$

Међу песницима уставобранитељске поезије издвајају се тројица: Сима Милутиновић Сарајлија, Јован Хаџић и Ђорђе Гроздановић. Они се издвајају ангажманом, обимом, истицањем емоција и квалитетом поезије. Први као песник Првог устанка и култа Карађорђа, а други као писац устава и закона. Док је Милутиновић писао похвале Вучићу, Петронијевићу, султану и турским пашама, Хаџић је славио побуњени народ, Карађорђа и његовог сина кнеза Александра. Гроздановић је опонирао првој двојици.

Код нас је увек постојала ангажована поезија, али су већ први наши критичари (Константин Богдановић) сматрали да када песме служе апологији носе негативан предзнак јер истичу неумереност песника, али ако песник сачува меру у изражавању те ангажованости може имати и књижевни значај.

У поезији песника овог периода једна од главних црта је претеривање сваке врсте, да би се окривила противна страна, па су повремено и стихови прелазили у псовачку поезију, као вид једног новог стваралачког осећања.

На челу политичке поезије са позиције уставобранитеља налази се Сима Милутииновић (1791-1848).

Био је истакнути уставобранитељ, који је провео тешке дане, а за прве владе кнеза Михаила (виђен је како са пиштољима за пасом шета улицама, због претње да ће бити ухапшен), морао се ставити под заштиту Турака у тврђави, и доцније отићи у прогонство. Као изгнаник у Видину био је значајна веза између представника уставобранитеља у Цариграду и Влашкој,

1 Д. Страњаковић, Влаgа Устиавобранийеља 1842-1853, Београд 1932, 5.

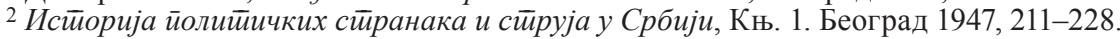


и оних који су остали у Београду и Србији. Тада се нарочито трудио да очува јединство међу изгнаницима и у најтежим данима, када је било неизвесно шта ће бити са њима, бодрио малодушне. О томе су аргументовано писали Ђорђе С. Ђорђевић и Владан Недић, али при томе нису користили богату песникову оставштину. ${ }^{3}$

Прве стихове уставобранитељске поезије почео је да пише у београдској тврђави (1840), када се ставио под турску заштиту, а продужио у Видину. Ту је започео и спев о Аргонаутима, који су пронашли и освојили златно руно (устав), а продужио је песмама пенегирицима и стиховима којима је омаловажавао Обреновиће. У прози је писао о уставном (правном) уређењу Србије.

Из изгнанства у Видину вратио се 18/30. новембра 1841, када је био у „радујевачком контумацу”, а после неколико дана приспео је у Београд. Са победом уставобранитеља почео је у Београду објављивати песме, посебно у неколико стихованих брошура, а у листовима Доgайак к Срйским новинама (1842) и Пояунавка (1843) разне пенегиричке песме. Стихови су у десетерцу римованом, са парном или непарном римом, али и у осмерцу. Ове осмерачке песме биле су намењене певању. У њима је славио народ, Карађорђа, кнеза Александра, значајне уставобранитеље, турске великодостојнике.

У спису Оиаклија Зубанова дао је стиховане портрете истакнутих уставобранитеља, Аврама Петронијевића, Лазара Теодоровића и Лазара Зубана.

У песми Дуел, написаној 4/16. маја 1841. у Видину, приказао је у алегорији борбу између Стојана Симића и кнеза Милоша:

Нехотчина, кано л’ простачина,

Алонза је Његул увреднуо,

Једном негда, и то једва игда,

Најфском мишљу, ил' грубима слови;

Ал' то ј’ на зуб Алонзо узео. ${ }^{4}$

Милутиновићу припада заслуга да први објави стихове у Кнежевини Србији уперене против кнезова Милоша и Михаила. Почео је у Доgайку к Срйским новинама, а наставио у Пояунавки, песмом „Разговор два Србина”, Драгутина и Милутина, под псеудонимом „Ч........”.

\section{Драїуйин}

Шта је ово данас опет

Куд одлазе људи ти?

Оружје им у рукама,

А весела лица сви!!!

Зар на дочек душманина

Отечества Србскога?

Ил' на свадбу и весеље

Пријатеља вернога?

3 Београд 1959, 151-179. (Одељак: „Уставобранитељи”).

${ }^{4}$ Пооунавка, 1843, I, 32 (7. VIII), 133. 


\section{Милуйин}

Није, већ на Врачар хита, Који како може сад,

Кнеза ново избранога

Срб је видит' сваки рад,

Пак му жели Народ цели

Живот, здравље за млого,

И да Устав свето храни, Да с' не брине за друго!

У песми су поменути сви од кнеза Александра, Аврама Петронијевића и Томе Вучића Перишића до Шекиб-ефендије и Ћамил-паше. ${ }^{5}$

Друга је Пјесна устиавовачка, написана „у Видину 5. маја 1841. године”, са припевом, који се после сваког двостиха понавља, а била је намењена певању:

Процвјетала гора и лужина, Састала се браћа и дружина, Уставовци, та Сербије синци, За правицу ради мученици.

Липар - башче Пазванџије давна

Глас оживља славујка свеславна,

Ал’ га Сербска преуслађа дружба,

У Цара је пријмљена јој тужба;

Цар Сербије саслуша молитве,

Од вражије спаса је ловитве,

Синци мајку опет' утјешају,

У натјеч јој руке љубежају,

Браћа сестре загрљају своје,

И дјечица сва весела поје:

„Благо нама с нашим’ старјешама!

Вјечна фала на свим’ старањама!

Враћаћемо ми потомству ова, Док прилика нам’ се јави нова!

Слава Богу на сунашца жару,

Но и Цару на правице дару!!!6

Следиле су песме, (неке су сачуване и у рукопису): Поіиб Устиава у Сербији; ...... Вучића?, Наяйлочно. Павлу Миловановићу, Серб-искреника узйлас,

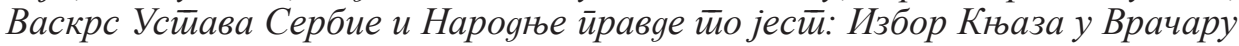
$1842^{e} \bar{i}$ og. $2^{a}$ Сейиемв.[ра], Усйановительу ірађанске јеgнакосиии у Турскомь

5 Дояайак к Срйским новинама, 1842, бр. 36 (5. септембар), 145.

${ }^{6}$ Истио, 1842, бр. 46 (14. новембар), 187. 


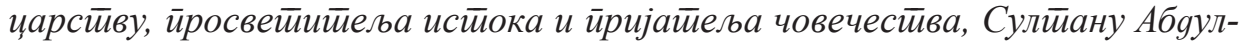
-Мецияу, Без наслова. (Поч.: „Ој Уставу, нам утјехе јаву”. Посвећено Јовану Хаџићу), Пой Илији Сйанојевићу Устиавиу; Честиитање курбан-бајрама Муса-йащи 1841; поменута Разіовор ява Србина, Пјесна устиавовачка, Мусса-ефеняји устиавовачки йойјев, По о облик Карађорђа, О лииу и gуху Карађорђа. (Ояривак из Оиаклије Зубанове 1840. ì.) йойјев, Дуел, О лииу и gуху Франклина. (Ояривак из Зубанове Оиаклије), Ояривак из Зубанове Оиаклије (штампане посмртно, 1853. године). Посебно су штампани: Васкрс усйава Сербије и нароgње йравgе (први, други и трећи, 1842-1843), Сербин [1842], Глас нароgа срӣскои [1843], Аманей Карађорђа на Делиіраяу. [Београд, 1843], Оgусовјеӣ Ђорђу Гроздановићу. [1843], Оوйјев на йреврайни сиирмоілав йреболесной Ивана Соколовића назови Каблариа. Оgъ зяравоїа Срба Србовића озбиљскоі Овчариа. [1843], На дочекъ Вучић-Аврамов 1844. іолине. [1844].

Тада се у нашој књижевности јавила и полемика у стиховима у памфлету Оgйјевъ на ирреврайниј сиирмойлав ирреболесной Ивана Соколовића назови Каблариа. Og зяравоі̄а Срба Србовића озбильской' Овчариа који садржи уобичајену шему. Милутиновић прво напада Обреновиће, а онда и самог Ивана Соколовића (често употребљава псовку и надимке „Жутовуговићу”, „Вугосмрдовић”, „Опрцановић”, „Цванцикаре”, „Шифљикаре”, „Тресиреповић”, „Лажиплетовић”, „Соколе Гушчић”, „Ронисузовић”, „Вињаговић”, „Добросав Паливоља"):

Ето преврат, ет' и стрмоглаве, Ал не Срба ни једног правога, То ли драге Србије нам мајке, Него твоја о соколска хрђо, Баш Раскњаза Обренбјеговића, И његовог друштва свеколиког!

Полемички интонирани стихови откривају и мало познате историјске чињенице о политичком деловању кнеза Милоша Обреновића. Посебно се износе недела Милоша Обреновића у самом устанку, његова у гушењу Хаџи Проданове буне:

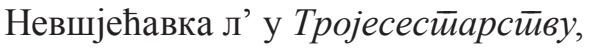

Предјавка је Милошева краја,

Да је Милош тек' разумјет’ хтео. ${ }^{7}$

Милутиновићево Тројесестиарстиво, стихована историја Другог српског устанка, која је изашла у Лајпцигу 1837, а у трећој песми која носи наслов: Невјешћавка (својачка) налазе се ови стихови. Милутиновић, у одговору Соколовићу, за горње стихове тврди да су били упозорење кнезу Милошу, али он то није прихватио. Због тога одговара Соколовићу:

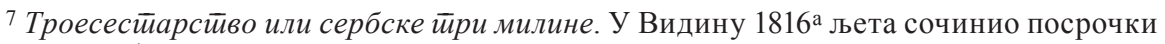
(и сад исправио). 
Шта л' си грдње ти на истог' писо,

На Милоша Обренбјеговића, По новинам' разним' од Европе, Кад је Милош остављао кнежтво, И кад’ Вучић живот му простио, Исти Вучић ког ти сада грдиш И хајдуком самим називаш га, А тад си га ти у звјезде ково.

Когно и ти славиш у новини Аугсбурга Њемачкога града, Ал ја ћу то јер о томе сумњо, Да ће моћи то њега тад постићи, Каква тад’ су Порте била доба. Анти султан посто у Египту.

Србија ће бити земља:

Ђено нејма буре и валова,

Нити стјена' ни подводни' пруда',

То ли мрака и грозни облака,

Тиранина сваком’ душманина.

За то се потрудио Вучић. Милутиновић оптужује и књегињу Љубицу да је упражњавала мађије, кнеза Михаила за убиство Милутина Гарашанина и његовог сина Луке. У истој песми хвали Стефана Книћанина, Стевана Миљковића, Илију Новаковића, Максима Ранковића, Пауна Јанковића, Стефановића Тенку, Луку Лазаревића и Петра Марковића.

На оптужбе да је Вучић Перишић био убица и хајдук, одговара:

Нигда није Вучић хајдуково,

Али јесте војник из детињства,

Безбрк ратник био Карађорђу,

Тек' кад би га ондак измјерио,

Кад је јапре он у војску пошо,

Па особно торбу и оружје,

И остало што војник носио

На своима плећ’ма јуначкима.

На крају завршава стиховима о Ћеле Кули и Ламартину:

Радије се куле подизају,

Од самије глава' јуначкије,

Но да с' нејма воље и слободе,

Под Нишом је таква једна кула,

Турци су је навлаш озидали,

Од Српскије глава Ресавскије, 
Каменица што иј погубила, Но на већу себ' и својим' бруку, А за спомен к' слободи љубви, Вољност воли и птица у гори, То ли човек здравога разума, Ламартин је ово примјетио, Кад' под кулом истом почивнуо.

Устав неда тиранству овлада.

Одговарајући на памфлет стихове Ђорђа Гроздановића, Милутиновић је у Ояусовјешиу Ђорђу Гроздановићу певао:

Још слепаца има у Европи, Ал' такога нема ни једнога, Што је Ђорђе Гроздановић овђе, Код очију он је брез очију, Код образа он је брез образа, Код Србинства он је брез општинства Гроздановић име му је Ђорђе, А то значи, кад’ га разум зрачи, Грешан-Кљуцо-Јагуридовићу.

Даље напада Милоша и Михаила и све чланове породице Обреновића (Јована и Јеврема, Љубицу), а истиче како је Порта за новог књаза означила Александра. Потом наводи Вучића и Петронијевића, Пауна Јанковића, борце за устав и народ. Песника Гроздановића назива „Пјеван Ронисузовић”, „Несрећковић”, „Гриздановић Грешо”, „Грешан Вињаковић”, „Грешова Вињага”:

Надми дипле и подапни гусле,

Тер да сита и до преко зуба,

Наурлај се кроз цјел простор Свјета,

Может' која врана и лисица,

Послушати, теб' се наслаждати,

И твојега грла и пјевања.

Све сохране у твоме Содомству;

Што извјестно j' паклу и Сатани

Ти да волиш све, чим' њима годиш,

Пак још зато на свјету те д’рже -

Још зла твога има опакога,

Ал’ бројит’ га, та ни мислити га.

И на крају:

Да Раскнеза више не гледате,

Он је био, пак је преминуо, 
И отац му сав се посвињио, Ништовићи Обренбеговићи.

И били су и остали су,

И то дјелма доказали свима,

Све и воде опрати не могу,

Ни сва пера зла описат њина;

Роб и слуга и надничар подли

Јесте њима Обренбјеговићма

И Добросав; зато ј’ Паливоља,

Лепо j' име, ал до њег' је зоља.

Књаз је српски Карађорђевићу,

А већ нигда Обренбјеговићу;

Пак све зоље ништ' спрам божје воље.

Ређали су се Милутиновићеви стиховани памфлети, у посебно штампаним књижицама, некада од неколико листова. Једна од већих песама је Глас нароgа срйскоі, који почиње стиховима:

Боже мили чуда големога,

Кад се Ђорђе на оружје диже,

Са помоћју Бога истинога,

И светога Студеничког Краља,

Он разгна Турке зулумћаре...

Тада је испевао На дочек Вучић - Аврамов 1844 (У Београду 17. августа), која је певана као корачница:

Пламћи, букћи, ура кликћи,

Срб-Народе, Срб-Устава браћо:

Ево нама Вучића!

Ев’ Аврама Србчића!

Бог нам иј је сачуво,

Цари нам' иј враћају,

Бог и правда још свијетом влада.

Овде треба поменути и Његоша. И он је поздравио ново стање у Србији. Уводну песму „Луче микрокозма” посветио је своме учитељу Сими Милутиновићу, која је кључ за разумевање овога спева, Његош посвету завршава стиховима:

Ја од тебе јоште много иштем!

Да поставиш у пламтеће врсте

Пред очима Србства и Славјанства

Обилића, Ђорђа и Душана.

И јошт кога Србскога хероја -

Да прогрмиш, хулом страховитом

На Вуицу, Вука Вукашина, 
Богомрске Србства одпаднике;

Злоћа њима мрачи име Срба,

Тартар им је наказа малена! ${ }^{8}$

На овај захтев Милутиновић је одговорио драмом Tpaīeguja вожga $\mathrm{Ka}$ paђорђ $а$, која је остала у песниковој оставштини и објављена је у данашње време настојањем и приређивањем Тање Поповић.

Иако је тежио да се приближи стихом народу, о уставобранитељској поезији Симе Милутиновића „на народну” писали су савременици 1843. године, да његова поезија „никако није народна; јер народан размјер није довољно да и поезија буде народна".

Песник који предводи ову групу солидарну са уставобранитељима је Јован Хаиић (1799-1869).

Када је кнез Милош абдицирао, Хаџић се нашао у новој ситуацији. Немири су почели, и борба између уставобранитеља и кнеза Михаила се водила и тајно и јавно, и Обреновићи су покушали да се реше Хаџића као писца закона, под изговором да је он прескуп за Кнежевину. До априла 1840. Хаџић је морао да изради збирку закона и законских прописа прилагођених Уставу. Када се ово приближило крају, влада је 21. августа исте године ослободила Хаџића свих комисија, како би се посветио Грађанском законику. У ово време код аустријских власти је Хаџић уливао свако поверење.

Када је почела буна кнез Михаило је затражио његово мишљење, али је Хаџић одговорио да се као човек од закона не може сложити са силом и зато се са својим законима склања у страну. И као човек од закона није волео револуције. Преко својих људи кнез му је поручио да се не меша у политику.

Као уредник алманаха Голубица, Хаџић (уређивао од 1839. до 1844), у години 1842. објавио је своју песме у алкејском стиху „Побуњеном народу у Сербији (на Топчидеру) месеца маја 1840. год.” Мото песми је мисао Хорација „Quo, quo scelesti ruitis? aut cur dexteris / Aptantur enses conditi?”, a песма почиње:

Безбожији род! - Паклениј л’ изроде,

Ил' чето дивја леса из зверскога,

Куд тежиш слепо с огњем силним, Љутим оружијем зашто севаш?

Са Колубаре, Друговца, Ужице,

Ваљевске стране, брзе Јасенице,

Од Чачка, и Бруснице мрачне, Многе што прогута врстне душе,

Кад се стремиш бурним' у јатама?...

Видим ја земљу ружно узмућену:

Срб Срба гони, скверном руком

Утробу Србије чупа грозно...9

${ }^{8}$ Београд, 1845, 10.

9 Дояайак к Срйским новинама, 1842, бр. 45 (7. новембар), 183-184; Голубииа за 1842, Београд, 143-145; Дела I, 129-131. 


\section{Следила је басна у стиховима Лисица и кокощи:}

У старо је негди било време

Одабрано кокошије племе;

А над њима лисац господару,

По судбине, слепе среће дару.

Од зла чува лисац своје коке,

Да им срдце све пишти од муке. ${ }^{10}$

Јовану Хаџићу припада заслуга што је у својој збирци песама објавио и коментаре о настанку стихова из уставобранитељског времена:

У оно време 1840. год. кад је кнез Михаило, Бератом Султанским потврђен, из Цариграда у Србију дошао, он је, особито још онако млад, врло тежак задатак имао. После оставке (1. јунија 1839) кнеза Милоша, отца његовога, цепали су се и чиновници и народ на две стране. Са удаљенијем његовим особито се сва породица Обреновића посрамљена и увређена нашла. Овога је наравно сљедство било жеђ за осветом против оних, које су они по свом уверењу за виновнике ове нанешене обиде држали; да се врати жао за срамоту. Врховна власт у рукама сина Милошева давала је и способа и начина лако се осветити моћи. А раздвојење неки' главни' старешина' и разстројавање чиновника' и народа, у коме их је долазак кн. Михаила заостао, томе је на руку ишло. Поглавице при удаљенију књаза Милоша бивше надале су се томе; и зато су зар настојавали код Порте, да се двоица њих уз младог младога кнеза као његови особито Советодавци поставе и бератом утврде, надајући се по свој прилици, да ће на таковом месту све умишљаје на освету против себе и своји' једномисленика' осујетити и одбити моћи. Но то управо противно дејство произведе, и ускори противоборство. Ово се узме за нарушење уставни' права', њима се припише, и послужи за повод подизања народа против њи. Са влашћу у руци лако је било на то коловође наћи, и ови доведу са сви' страна' народ с оружаном руком у Топчидер, са виком против Советодаваца књажески’ Вучића и Петронијевића, па после и њихови' неки' једномисленика. Песник је у ово време радио на сачињавању закона' у Београду. Он је био свију дела' очевидац. Књаз са главним' својим чиновницима, као и с књагињом матером и сроднима, често је излазио у Топчидер к тако побуњеном народу. Позиван је био и Песник више пута', и у разговору питан, како се њему то допада; на које је он одговорио, да се њему никако допасти не може, почем је он човек од закона, па то са своје точке сматра, он види да у побуни овој сила влада, где пак сила влада, ту закон посла нема, па он сад са законом треба у страну да иде и ћути. И другима старешинама, који су га запитивали, како му се допада, одговарао је обично: „Никако! Јер он мисли, ако је намера, опростити се наметнути” несносни' Советодаваца Вучића и Петронијевића, то је књаз имао за то стотину начина' бољи' и безопаснији од буне, која му се види као најгориј и најопаснији начин, тако, да Бог сам зна, како се свршити може”. Овако негодујући

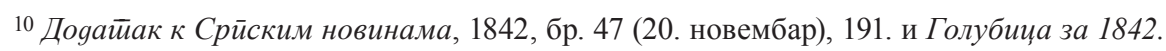
iоoину. 
Песник ову побуну, којој је народ узмућен, излио је мисли и чувства свија у Песни овој. ${ }^{11}$

Исте године и у исто време написао је песму у осмерцу: „Коме птица певала? (по народној приповедки"):

Два су друга путем ишла;

Украј пута на гранчици

Певала је птица једна

Гласно, лепо, и весело!

Једна рече: „Мени пева”.

Другиј вели: „Мени пева”.

Један другом не попушта,

Свакиј себи песму своји.

Тербу носе на кадију,

Да кадија право суди,

Коме птица песму пева.

(У Београду 1840)12

Исте године је написао и песму пријатељу Симићу „Утеха Г. Стојану Симићу. 20-ог марта 1840. у Београду”. У њој теши пријатеља да је тешко време прошло и да је „Премалеће дошло” (Устав дошао).

Што си брижан, смућен, Стојане?

Зашто седиш, идеш без воље?

Та што је било, прошло је,

А премалеће дошло је.

(У Београду 20. марта 1840).

У коментару уз ову песму пише:

Од времена Милетине или Симићеве буне (јан. 1835) и у следству ове сљедовавше Скупштине Сретењске (2. фебр. 1835) Старешине су Србске колико по уверењу своме толико по крајњој нужди све тешње скопчавале се у слогу и дружство, настојавајући, да се самовољство књаза Милоша ограничи, и безбедност личности, имања и чести свакоме Србину прибави. Оваковим настојавањем дошло се до Устава 1838. године добивеног, и у пролеће 1839. год. обнародованог. Књаз Милош ипак покуша надбити ову победу Старешина, из потаје буну дигнувши код регуларног војинста против Устава и Старешина'. Но овога покушанија он сам жертва буде, тако да је притешњен 1. јунија 1839. оставку на књажеско достојинство у ползу сина свога најстаријег дао, и из земље изишао. Но колико је пре тога Старешине Србске страх од кн. Милоша у једно збијао; толико су се сад, како су се овога ослободили, одма цепати и раздавајати почели. Већ при првом почетку и постанку Намесничества до-

11 Дела I, Нови Сад, 1855, 199-201.

12 Истио, 132. 
стојинства књажеског, кад је Вучић неке себи неугодне чиновнике самовољно и без суда прогнати хотео, распре и цепања су се породила. Неки су у том поступку сматрали први корак новог самовољства, од кога су се једва јуче опростили, нити су допустити хотели, да Вучић од сад чини, против чега су у Кн. Милошу сви до јучер ишли и радили. После смрти Миланове буде млађи син Кн. Милоша Михаил за књаза код Порте предложен. Овај је онда у Влашкој код отца био, и због затезања и задржавања отчина дуже се онде задржао, тако да је доцније у Цариград ради потврдителног берата отишао, и тек у пролеће 1840. год. у Сербију као књаз дошао. Чим се долазак књаза Михаила већма протезао, тим је у Сербији раздор раст'о, и распростирао се. Старешине су се већма раздвајале, један другога понизити и у сенку бацати старао се. Од старешина' прелазило је на чиновнике остале, на војинство регуларно, и у сам народ. Све се поремећавало и разстројавало. У оваковом стању их је и долазак књаза Михаила застао. Стојан Симић, који се онда Вице-Председатељ Совјета био, и сам је једно од главнији дејствујући’ лица' у томе био. Великиј зајам, који је он после удаљенија књаза Милоша од Правитељства узео, давао је повода и оружија супарницима њега у поверењу поколебати, и сенку на њега бацити. Песник је онда, радећи на устројенјама земаљским, са Старешинама у непрестаном сношенију бивао, све те смутње и неприлике очима гледао. У таком стању видећи Стојана Симића мучна и невољна, седне, и напише му „Утеху” ову, из које се и стање и отношеније ондашње Старешина' видети може. Песник таки у првој строфи пита, зашто сад да невољан буде, кад је оно, што су желели, добивено, тј. прошло је време самовољства и силе, дошао устав и закон (премалеће или пролеће); њихову тежњу и радњу пред народом и са народом да се од самовољства ослободе и под крило устава и закона дође, уподобљава летењу ждравлова, кои беже од хладнога предела и иду у топлији; представља, како су се ови раздвајали и опет сложили, па су им и вође и јато лепо топлиј предел уживали. Од тога пример нека узму и Старешине Србске сад раздвојене, од коих су четири главна у место свију именована: Јефрем Обреновић, Аврам Петронијевић, Тома Вучић Перишић... ${ }^{13}$

Уследили су Хаџићеви стихови посвећени „новом кнезу” Александру, у осмерцима и седмерцима „Светломе Књазу српскоме, Александру Карађорђевићу 26. октобра 1842.”:

Што се ведри небо с југа, Зашто блиста вишњиј зрак?

Да л’ Ангела јавља дуга, Да разгони адскиј мрак?

Ил' Бог пружа десну руку, Да подигне Српскиј род,

Да утоли тешку муку, Шиљућ’ с неба рајскиј плод?

(У Београду 26га октобра 1842). ${ }^{14}$

${ }^{13}$ Ист̄о , 145-146, 209-211.

14 Дояайак к Срйским новинама, 1842, бр. 44, 31. октобар, 179; Дела I, 137-138. 
Када је Александар изабран за кнеза по други пут, подражавајући народну песму написао је у десетерцу „Песма српска пред избор другиј књаза Александра Карађорђевића, на Видов дан 15. јунија 1843”:

Боже милиј, чуда невиђена!

Што је сунце тамом помрчало

Виш' Србије на небу ведроме?

Да л' застиру облачине црне?

Ил' се вију над облаке Виле?

Ил' се бију змаји и аждаје?

Није оно сунце помрчало,

Виш' Србије на небу ведроме;

Нит' застиру облачине црне,

Нит' се вију над облаке Виле,

Нит' се бију змаи и аждаје;

Већ' је оно од Србије правда...

А ову слободу су помогли орао руски цар Николај, змај турски АбдулаМеџида, и орлови немачки, енглески и француски. У коментару је написао:

„Познато је, како је 1842. год. у Србији буна се родила, како је кн. Михаил земљу оставити морао, и син Карађорђев за књаза изабран, и од Порте беретом потврђен. Познато је и то, како на овоме није могло остати: почем је Русија као покровитељица Србије глас свој против тога код Порте подигла, и сматрала је избор овај као произлазак буне, која не сме да буде. Зато је захтевала, да се поглавице побуне те Вучић и Петронијевић из земље удаље, да се избор овај уништи, да се народна Скупштина сазове, и на тој избор слободан учини; и да Русији није стало до лица, но до основа. Порта, премда је од Енглезке и Французке, па и од Аустрије, у почетку подржавала захтевање Русије попусти, и поиште, да кн. Александер оставку да, и да се нов избор учини. И на ово књаз Александер да оставку, наравно са жељом да на предстојећој Скупштини опет за књаза изабран буде. Једно између остали' средстава', коима се народ за то преправљао, била је и песма ова од Песника народним духом спевана, и тако удешена, да су је гуслари у народу певали". ${ }^{15}$

Јован Хаџић је био творац првог српског Грађанског законика, који је српска влада издала 1844. године, али је ипак 1846. године увређен од Вучића напустио Србију. Консултовали су га крајем августа 1847. године због питања наследног кнежевског достојанства у породици Карађорђевића. Лично га је у Новом Саду посетио Миливоје Петровић, а своје мишљење о овом питању послао је и Книћанину 31 . августа 1847 . године.

Ђорђе Грозяановић је био најзначајнији песник, са највише објављених стихова, из табора Обреновића, који се под псеудонимом „Иван Соколовић”, у посебно штампане три песме, супротставио уставобранитељским стихо-

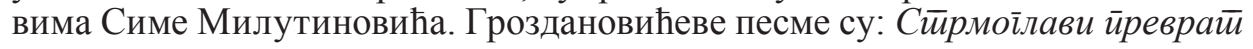

15 Дела I, 139-142, 204-205. 
Србије или Ойисаније созаклетиија Вучићевача и Турака йройив књаза Миха-

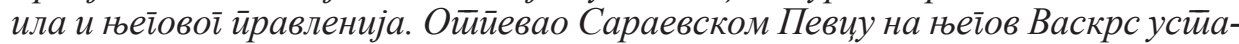
ва (Нови Сад, Писмени Катарине Јанковић, 1843; друго издање: У Земуну, печатано Књигопечатњом И. К. Сопрона, има 31 стр.), Сйрмоілави йреврай Србије. Продуженије оййева Певцима Псевgо-устианичким и новинарима срйским, свезка друга (Нови Сад, печатано Писмени Јована Каулиција, има 88 стране - доживела је два издања, оба 1843. године), а трећа је остала у рукопису, данас се налази преписана руком Симе Милутиновића у његовој оставштини. ${ }^{16}$ Десет примерака прве штампане песме послао је Лазар Исаковић из Земуна 15. јула 1843 . године кнезу Милошу у Беч. ${ }^{17}$ Да је ово псеудоним Ђорђа Гроздановића сматрао је Драгослав Страњаковић. ${ }^{18}$ Гроздановићеви стихови против уставобранитеља појавили су се и 1851. године. Ова нова песма, растурана у народу, састављена је код кнеза Милоша, али како је у њој нападана поред кнеза Александра и његове владе и Порта, српска влада је предузела кораке да се званичници у Цариграду упознају са овим стиховима. У писму Алексе Симића Книћанину од 21. октобра 1851. године наводи се да је песма од Ђорђа Гроздановића „Онога што је 1842. године писао Сйрмойлав Србије".

Личност Ђорђа (Георгија) Гроздановића, писца, писара, трговца (?, око 1805 - ?, после 1862), и данас није јасна. Из оно мало података знамо да је завршио основну школу, али није познато где. Радио је 1823. као трговачки калфа у радњи свога брата од тетке Ђорђа Стојковића у Београду. Трговао је стипсом, „стрешом” и другом робом, коју је довозио и на панађур у Приштину. Касније, 1834, живео је и радио у Бољевцу (Срем), где је имао своју радњу. У време доласка уставобранитеља на власт живео је и радио у Београду, а онда је као присталица Обреновића 1842. протеран из Србије. Као изгнаник живео је у Земуну, 1846. и 1847. боравио у Видину, где га је аустријски конзул Марко Добросављевић примио у службу за визирање пасоша. После краћег боравка у Свиштову и Рушчуку 1848. прешао је у Влашку (Ђурђево, Браила, Галац), а 1849. дошао је у Букурешт, где је провео четири године као писар Милоша Обреновића. Био је у пратњи Милоша Обреновића на путу за Беч, где је 1853. присуствовао свадби Михаила Обреновића. После седамнаест година странствовања, 1859. поново се вратио у Београд. Објавио је у три књиге стихова Ойисаније живойа Њейове свейлостии књаза Милоща Т. Обреновића (Београд 1859; Земун 1860; и Београд 1861). Поред овога написао

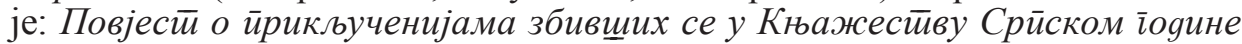
$1842 .{ }^{19}$ и Крваво иоозорје међу Турком и Србима у Беоіраяу $1862 .{ }^{20}$ Када је Драгослав Страњаковић приредио друго издање прича о кнезу Милошу Милана

16 О овој песми видети опширније: Станиша Војиновић, „Два песника из времена Вучићеве буне", Мещовийа ірађа - Miscellanea, књ. XXXVI. Историјски институт, Београд 2015, 141-182.

17 Архив Србије, КK, XL, 369.

18 Влаgа устиавобранииееља 1842-1853, Београд 1932, 143.

19 Списан Ђорђем Гроздановићем. У Земуну (друго изданије). У Земуну, печатано књигопечат. И. К. Сопрона 1859, 24 стр. (Стојан Новаковић, Библиоірафија, Београд 1869, 403-404, бр. 2199. Новаковићева напомена: „Не могох ништа сазнати за прво издање”).

20 Београд, шт. Н. Стефановића, б. г. (вероватно 1862) 36 стр. - Књигу поседује Библиотека Матице српске у Новом Саду. 
Ђ. Милићевића (књига није датирана, али је из тридесетих година XX века) пренео је и неколико Милићевићевих података о Ђорђу Гроздановићу: „Године 1842. овај Ђорђе Гроздановић, приморан оставити Београд и прећи у Земун, одонуда је писао брошуре у стиховима, и нападао и ружио Вучића и његову дружину. Одовуд из Београда Гроздановићу је одговарао Сима Милутиновић, који је био са уставобранитељима. Оно што је писао Гроздановић и његови другови преношено је у Србију кришом и овде преписивано, и разашиљано пријатељима Обреновића, а Милутиновићеви су стихови штампани у Државној штампарији, и власт их је преко кметова шиљала у народ. Ја сам онда још био у Рипњу, и у нашу кућу допирали су и једни и други ти састави, пошто је у целом селу мој отац био најписменији човек. И данас се сећам неких почетака тих братских милошта, којима су једни друге почашћавали. Тако, колико се опомињем, једна Гроздановићева песма почињала је овако:

Чуј, народе, видите ли, Срби?

Како с' уп'о сарајевски певац,

Из свег грла и из свега гласа,

Да прослави Мухамеда свеца?

У зачеље своје песме ставља

Ћамил-пашу, тиранина клета

Чивутина и потурчењака,

До Ћамила Аврама Ћехају,

До Аврана чкиљава Вучића,

До Вучића кусога Пауна (Јанковића)

До Пауна пијана Ресавца,

До Ресавца луду будалину

Будалину Книћанин-Стевана!

Даљих се стихова не сећам!"21

Ово чега се Милићевић сећа, то су стихови из песме: Сйрмоіллави йре-

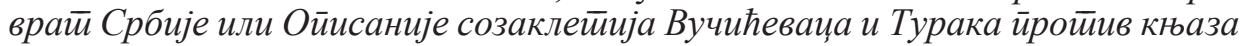
Михаила и њеі̄овоі̄ йравленија. Ойиеевао Сараевском Певиу на њейов Васкрс устиава (Земун 1843), али су стихови понегде нетачни и редуковани. Почетак овако гласи:

Чујеш роде, видите ли Срби, Како с' уп'о сарајевски певац, Из свег грла та из петни жила, Да прослави Мухамеда Свеца, И његове крвожедне Турке;

Коловође л’ бунтовнички чета? А помрачи славу Обренову.

${ }^{21}$ Кнез Милощи у иричама, Народно дело, 359 стр. Има 285 прича са сликама и предговор, стр. XVII-XXXII. 
Остале личности се помињу у доцнијим стиховима, али са тачно наведеним атрибутима. Ову песму Гроздановић је потписао псеудонимом Иван Соколовић у Каблару. Друго издање, на њему тако и пише изашло је у Земуну, и то је оно које је кнезу Милошу послао Лазар Исаковић. Нападајући Милутиновића, Гроздановић је сматрао да је он порекао своје стихове из

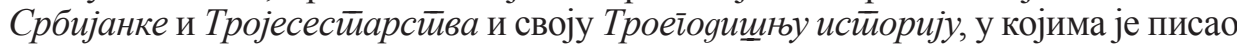
објективно и као песник и као историограф. Али у уставобранитељским стиховима.

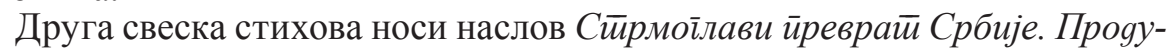
женије ойијјева Пјевцима йсевgо-устианичким и новинарима срйски написано је од истог Ивана Соколовића „у Каблару На спасов дан”, опет Гроздановићев псеудоним, а почиње стиховима, којима се завршава прва:

Тек што ј' набризгала чарна, Да развије свој брснати пупак, И одјене с' зеленилом дичним, А разаспе мирис од бехара, По пољама и по друбравама; Румена се указала зора, Виш' Србије на небу мрачноме, Јарко сунце топле своје зраке, Са висине просипати стало Да обасја уцвељену мајку; А огреје сиротињу српску, Која главе подигнути несме, Нит' у јарко погледати сунце, Од Мујкана душманина стари', И од лажи устав-бранитеља.

Гроздановић веома вешто подражава стихове Милутиновића:

У блажена преноси жилишта

Ток времена да задржи мисли

Види се да је Гроздановић био упознат и са везама уставобранитеља са Чарториским у Паризу:

Оправили чак у Париж тамо, С Чарториским чинит' преговоре

Он са друштвом кад се на пут спрема, Прек’ Ливорна у Србију доћи, С товарима новац' и џебане, Подпомоћи ајдучине српске; Тад Пољаци, Власи и Молдавци, Сви о једном оружија с' лате, Срб-Мујкан’ма у помоћ прискоче... 
Нова, уставобранитељска власт:

У облаке с' под небеса дижу,

А од паре маглуштина густа,

Сву Србију да покрије тамом,

И помрачи на вјек Српства сунце.

Гуске гачу подигнувши главе,

Ко да пјесне извијају њеком;

Мечке држе публичне балове,

А мајмуни осветљење праве,

Курјачина свије оштри зубе.

Боже мили, шта то може бити!

Песник је поред зала које су донели уставобранитељи, опевао и злодела Карађорђа у устанку (отимање Марије из Бруснице, од мужа Петра Николића; узимање каде Аганлијине; бешчашћење ћерке Обрада Словића из села Грабовица; отимање Миленије, жене Лазе Стаишовића из Жабара; Стаменије, жене Величка Ћорпетровића; прогањање тобожњих вештица). На крају је навео да, када је Карађорђе побегао из Србије, на Прогару, Милоша су звали Ненадовићи да и он бежи, а он је преноћио код попа Живка и вратио се у Србију:

Плач и јаук разлеже се тужно, Све оставља постојбину своју, Дом, жилиште, стада и имање, Према с' к рјеци на обалу туђу, За избавит' слатки овај живот. Још Неготин брани храбри Вељко, Јошт Војводе по међама стоје. И чекају, да с' одупру Турком, А незнају, шта се амо збило, Да је Ђорђе оставио народ.

Кад о бјегству Кара-Ђорђа чуше, Све потмуше Војводе тужно, Куд ко знаде там’ и надре пређе. Храбри Вељко погибе јуначки; Само оста Обреновић Милош.

Опевао је кнеза Милоша како је заклањао народ, подизао порушене цркве, отварао школе, сузбијао самовољу, старао се о независности Србије.

У фусноти 40 (стр. 43 ове књижице) „објаснио” је и смрт Карађорђа, а поменуо је и спис Симе Милутиновића Глас нароgа срйской (објављена је анонимно, коју назива пасквилом, и за коју погрешно претпоставља да ју је написао Паун Јанковић). На следећим странама у стиховима и фуснотама уз њих полемише са аутором овога списа, бранећи убиства кнеза Милоша. На- 
води доброчинства кнеза Михаила (помоћ комесару Муса-ефендији, уставобранитељима у Видину и Цариграду, њиховим породицама у Београду, богаћења истакнутих уставобранитеља у Влашкој, наводећи суме у талирима, пореклу уставобранитеља). На крају закључује да су „Псевдо-уставовачки пјевачи проузроковали садашњи метеж у Србији”. Да њихови памфлети и пасквиле само говоре у прилог њиховог бешчашћа, због чега је Вучић наградио новинара Теодора Павловића, уредника Срйског̄ улака Јована Хаџића и његовог помоћника Максима Симоновића, Милоша Поповића, уредника Пооунавке:

\footnotetext{
О пјевачи Псевдо-уставачки!

Па спјевате Химне недостојним,

Уносите више сунца јарка

Корифеје и изроде Српства.

Тако исто Кара-Ђорђа грозна

Узносите хвалам' до небеса

Да је већи јунак и благодеј

Од француског цара Бонапарте.
}

У даљим стиховима нападају се песме Симе Милутиновића и Јована Хаџића због закона. Ту он у прози (фусноте) доноси податке о неким сусретима Хаџића са кнезом Михаилом у Земуну. После тога доноси регистар злодела Томе Вучића Перишића. На крају поручује уставобранитељима:

Свези свезом Свемогућства Твога

Сојуз тврди и вјекове вјечне,

Мир да прави, и поредак добри

У земљама и народма влада,

Одржи се и утврди крјепко.

Злоковарни Корифеји грозни,

Бунтовници и немирне главе,

Који руше царства и престоле;

Који руше благостање опште,

Утамане с' да им нема трага!

Међу песницима са пасквилама против Обреновића у овој песми посебно Гроздановић истиче: „Пјесму српског имена” Ђорђа Г. Петровића и „Првиј Васкрс устава и народње правде у Србији” Симе Милутиновића, „коју је Вучић по сокацима носио, и светини читати дао, говорећи: ево браћо Васкрса устава, сад нам је устав васкрс'о итд." Даље Гроздановић наводи Милутиновићеве радове: „Разговор два Србина Драгутина и Милутина”, „Честитање Курбан'-Бајрама, Муса паши, пјесна уставовачка у Видину 5-о маја 1841”, „Васкрс Устава и народне правде у Србији”, „Муса Ефендији уставовачки попјев”, „Оплач”, „О лицу и духу Карађорђа (одривак из Оџаклије Зубанове 1840. године)”. Поред тога Милоша Светића (Јована Хаџића): „Оду Александру Карађорђевићу”, „Побуњеном народу у Србији на Топчидеру месеца маја 1840”, „Лисица и кокош”, и песме других песника. 
У Новом Саду је 1843. године објавио у стиховима Повјести о йрикљученији збивщесја в Кнажесвстивје Сербском љетиа 1842. списана Ђорђем Гроздановићем Земунцем. ${ }^{22}$

У предговору осуђује непријатеље који са Вучићем на челу желе да униште српски народ, подвлашћујући се Турцима, насупрот кнезу Милошу, који је целога живота желео да народ ослободи. Стихови су са парном римом, најчешће од дванаестерца до четрнаестерца.

Почиње сликањем тешког стања узбуњене Србије:

О Сербијо мила, што си потавнила, Што си тако ниско главу оборила,

Као да ти се гуја, крај срца савила, Зар те опет стрела какова ранила.

а продужава истицањем значаја кнеза Милоша:

Милош да вам живи Обреновић стари, Слободу вам доби а Турке сатари.

Скинути вам јарам, труде не пожали, Околне дворе молити навали.

За Сербију јадну, да се смилуједу, Од Зулума Турска, да је ослободиду.

Истиче његове заслуге и успехе, припајање нахије 1833. године, подизање цркава, градњу карантина, набавке оружја и установљења војске, организовао је путовања по Европи кнегиње Љубице и кнежевића Милана и Михаила (а овом последњем омогућио да савлада француски језик), увео школе, омогућио да се са страних језика преведу уџбеници, позвао уметнике у Србиjу, насупрот Вучићеваца, који су прогнали кнеза Михаила, учене Србе, и многе занатлије и трговце. На крају пише да „продуженије следује”, а у наставку је „Пјесма Београду у садашњем состојанију на тропарски глас 8-ми”, који почиње тужбалицом:

Преобразилсја јеси Београде,

Украшенија и слеве лишисја,

Паденија и угњетенија удостојсја;

Гдје је слобода гдје ли слава Сербије

Прогна Вучић и, уничтожије:

Злобном похотом прогна Михаила.

После повратка кнеза Милоша у Србију 1859. настанио се Гроздановић у Београду и, како бележи Милићевић, „боравио је у Скопљанској улици, онде где је сада нова кућа Јевгенија Чоловића. Чини ми се да је онде и умро, али не знам које године. Иако сам много распитивао, нисам могао ништа више сазнати о овом Гроздановићу".23

22 Нови Сад, Писмени Катарине Јанковић вдове, 32 стр. Примерак поседује Институт за српски језик у Београду.

${ }^{23}$ Кнез Милощ у йричама, Народно дело, 359 стр. Има 285 прича са сликама и предговор, стр. XVII-XXX̄II, 356-357. 
Писац ових редова истраживао је архивску грађу о Гроздановићу, и осим једног његовог писма и неколико потписа (једанпут се за њега потписао његов син Душан) није нашао ништа о њему.

У Букурешту је сачинио песму у којој се нападао кнеза Александра, његову владавину и Порту. Милош Обреновић је преправио неке делове ове песме, штампао је и 500 одштампаних примерака послао тајно у Србију, да би се разделило народу. Ова књижица је, по суду тадашњег министра просвете, утицала на ток ђачке скупштине која је одржана на Видовдан 1853. у Београду. Гроздановић је према кнежевом усменом саопштењу саставио биографију у стиховима, по узору на народну десетерачку поезију, и објавио прву свеску по повратку у Београд, захваљујући јемству за штампарске трошкове ћурчије из Београда, а следеће две уз помоћ пренумераната и Обреновића.

У оставини Симе Милутиновића налази се рукопис песме, преписане његовом руком, под насловом „Одгрда на Одусовјет, Сими Милутиновићу Сарајлији. Од Грђенога усовјетствоватеља Ђорђа Гроздановића Земунца". Она има мото:

Чујдер мото бошњачка наврто?

Грди Грдо! Док идеш узбрдо,

И док' ти је под ногама тврдо,

Али кад се надоле повратим,

Тад ћеш доћи дугове да платиш.

Садржи све оно што је горе речено, а колико је нама познато није нигде објављена. ${ }^{24}$

\section{ОСТАЛИ ПЕСНИЦИ}

Ђорђе Малейић (1816-1888) је у јеку уставобранитељске кризе после

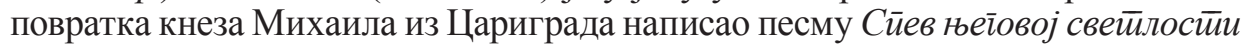
милостиивејщему іосйоgару и књазу србском Михаилу Обреновићу ириликом gолазка ґейовоі̄ из Цариїраgа, панегирик у којем је славио кнеза Михаила. ${ }^{25}$

У Срйском наровном листиу Теодора Павловића објавио је песму посвећену кнезу Михаилу Аустиријска муза у Сербији, у којој пише:

Надеждо сјајна. Обрано, Заштито

Премила правде, Кнеже Михаило!

Дај, рјеши судбу над бесмртном, (Теби јер дадоше Бози силу);

Дај, стави, Мили, подле противнике

И дјела м' сјајна златно на мјерило:

${ }^{24}$ Архив САНУ, 14161/367.

25 У Београду, печатано у књигопечатњи Књажества Српског, 1840, /6/ стр. 
Претегну л’ они лавров вјенац

Чело што краси ми навјек свјетло. 26

Биографија му је веома занимљива. Српску основну школу је завршио у Јасенову (у Банату), немачку у Белој Цркви, гимназију у Ораховици и Сремским Карловцима, филозофију (VII и VIII разред) у Сегедину. У Србију је прешао 1838. и био помоћник судског секретара у Крагујевцу, секретар Министарства унутрашњих дела, па секретар Управе града Београда (18391841) и секретар агенције у Букурешту (1841-1842), дневничар у Министарству просвете (1842-1844). Када је отпуштен из службе живео је у Земуну од књижевног рада (1844-1847). Вратио се у Београд и био учитељ деце Јеврема Ненадовића (1847-1848), професор Лицеја (1848-1859), па онда директор београдске гимназије (1859-1878). Године 1874. вршио је дужност управника Народног позоришта.

У рукопису је остао позоришни комад Вучићевцุи и књажевии, комедија која представља интимни обрачун Малетића са уставобранитељима, и актуелну реакцију присталица кнеза Михаила на њихову владу. То је први покушај политичке сатире код нас, у чему је значај овог драмског дела.

Време догађања у овој комедији је Земун 1844. године. Главна лица су Анта, збачени чиновник (Вучићевац) и Влајко пропалица, који по Земуну агитују за Вучића. У љубавној причи неостварене љубави, радњу заплићу слуге: Станимир (Антин) и Стојко (Влајков), који помажу да се Антина кћерка уда за Смешка, столоначелника Попечитељства у Србији и члана Совјета. Ћерка Антина Босиљка, која жели да се уда из љубави, и воли Младена трговца, супротставља се овој очевој жељи.

Тайомир Миловук (1809-1878) је занимљива личност XIX века, који је рођен у Трпињи у Срему 1809. године. Учио је шест разреда гимназије (18261828, и красноречије 1829-1932) у Осијеку, потом две године Богословије у Сремским Карловцима (1832-1834). После преласка у Кнежевину Србију радио је као канцелиста у Кнежевој канцеларији (1834), учитељ у Смедереву (1834-1838) и Пожаревцу (1838), професор гимназије у Крагујевцу (1838-1842). У време уставобранитељске кризе отпуштен је и фебруара 1843. био је учитељ у Грабовцима код Варадина (1843/44), Добановцима (1845-1848) и Бешенову (1848-1849). Био је секретар на скупштини граничара Петроварадинске регименте у Митровици 8/20. IV 1848. и учествовао је у Револуцији. Потом је био парох у Оролику код Винковаца (1852), Вуковару (1852-1860), Новом Саду (1861-1862, 1864-1865) и Лазу, у Бродској регименти (1864). У Кнежевину Србију вратио се 1 . X 1865 . и био парох у Ћуприји (1865-1867), управник приватног дечијег обданишта у Београду (1867), парох у Породину у Пожаревачкој епархији (1868-1871) и селу Батуша (1871-1874). На сопствену молбу и жалбу Народној скупштини добио је пензију 25. I 1876, а умро у Београду 19. XI 1878. године. Сарађивао је у алманаху Уранија (1837), Срйском нароgном лисӣу, Србобрану и календару Гоgищъак, а објавио је и неколико панегирика у стиховима (поред осталих и кнезу Милану, 1869, 1871, 1872). 27

${ }^{26}$ Срйски нарояни листи, 1840, V, 30 (25. VII), 233-234.

27 Радомир Ј. Поповић, „Татомир Миловук”, Сйоменица Истиоријской архива „Срем”, 12 (2013), 13-34. 
Оно што је значајно за ову тему, под псеудонимом Светород Журналовић, објавио је у посебној књижици Укор на бунимовне Србе. Сйисан 1843. loguне у Србији. ${ }^{28}$ Да је он аутор открио је сам Миловук, у писму кнезу Милошу из Новог Сада од 20. јуна 1843. године, са којим му је и послао 12 примерака ове књижице. ${ }^{29}$

Као мото су му послужиле српске народне пословице, а песма почиње стиховима:

Боже Мили чуда големога, Гледа чуда никад невиђена, Гди подани своме Владетељу, Господарство отеше ајдучки.

За недела уставобранитеља (које назива „Уставокваритељи”) наводи примере и критикује новине које „грде Милоша”, а за недела Карађорђа пише:

Карађорђа примера скаредни, Још би могли стотинама наћи Што сведочи Чубре Сербијанка.

Истиче кнеза Михаила, који се научио „Политичном језику Французком”. А онда доноси негативне карактеристике Александра Карађорђевића, његове испаде са професорима који су га поучавали. Објашњава и како је Карађорђе страдао у Србији, и наводи претњу везира београдског кнезу Милошу, да ако му не донесе главу Карађорђа замениће је његовом.

Димитирије Нещић (1817-1867), правник по струци, био је као песник

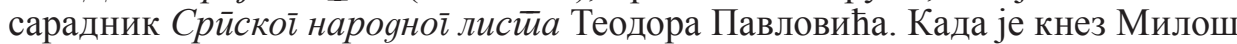
абдицирао, под иницијалима Д. Нћ објавио је песму „Столпницима. Србљи! Богови”, у којој има стихова о јунаштву Обилића и Марка а у строфама 11-15 следеће:

Мајку? - С пута кои тако не мисли! -

Пантеон отварајте Браћо Србскиј,

Пейронијевића стављајте

Мудрог, тихо - разсудљивог

Јефрема, Обилића Вучића,

Оштрог Симића, тврду и

Јуначину Раgојковића,

Столпове као сјејне Србске.

${ }^{28}$ Нови Сад, 1843, 32 стр.

${ }^{29}$ Архив Србије, КК, XL, 384. 
Китњасте им разнашајте Перјанице

Гласно, до студењи крајева.

Ободрајте и љубвом, срдца

Искреношћу, наклоношћу

Вером, ту им јер награду срдце

Од Вас чека. - Бог а времена

Достојно умеће ом боље

Славна увенчати дела!!!30

Године 1842. издао је збирку песама под насловом Сйихойворенија, и када је Михаило ступио на кнежевско место написао песму „Његовој сијателности государу Михаилу Обреновићу књазу српском" (стр. 7-12). Једну песму посвећену кнезу Михаилу послао је Министарству иностраних дела. ${ }^{31}$

Паун Јанковић Баћа (1808-1865) је један од истакнутих уставобранитељских првака. Писао је песме и 1841. године у пештанском Срйском нароgном листиу Теодора Павловића објавио, под шифром „А” песму „Похвала месецу”. Ову песму је редакцији листа послао Сима Милутиновић из Видина. Посланица почиње стиховима:

У злоудој тековини,

Кои својој домовини,

Као слепац, ломи врат,

С братом своим није брат;

Своју сестру, свога друга

Сматра мерилом услуга!

Ах, тиране, аветињо!

Чудо света, проклетињо!

Докле ће твој буздован

Одолеват' правде стан;

Кости свету пребијати,

Перуном се називати? 32

Сйаноје Ћосић (1803-1847) је песник који је певао Обреновићима (кнезовима Милошу и Михаилу), али је у јеку уставобранитељске кризе покушао да заузме неутрални став, сматрајући да ће се нашим сукобима користити само непријатељи. Он је посебно 1840. године објавио песму под насловом: „Песма народу српском о збившем се у времену године 1839 , и о пришествију Његове Светлости Књаза Михаила Обреновића, из Цариграда у Србију 2. марта 1840". Међутим оно што је много значајније су његови рукописни стихови, који су се ширили у народу преписивањем, и због којих је испитиван од стране полиције. Стихови су сачувани у Министарству унутрашњих дела.

30 Д. Нћ/Димитрије Нешић/, Столпницима. Србљи! Богови (песма), Срйски нароgни листи, 1841, VI, 35 (31. VIII), 269.

${ }^{31}$ Архив Србије, МИД-В, 1841, V, 124.

${ }^{32}$ Срйски наровни лист̄, 1841, VI, 12 (20. III), 89-90. 
Песма има 296 стихова и датирана је у Сремској Митровици 20. маја 1840. године. Почиње стиховима:

У хиљаду и осме стотине Четрдесет текуће године

Књигу пише Босна земља равна Којано је позната одавна

Те је шаље богатој Србији, И у књизи овако говори:

Ој, Србијо по богу сестрице И одавно мила комшинице

Ево има дваест и шест лета

Како теби душманин не смета... ${ }^{33}$

У другој књижици стихова „Стрмоглави преврат...” Иван Соколовић (Ђорђе Гроздановић) поменуо је (стр. 69-71) и остале песнике уставобранитељске поезије: Владислава Стојадиновића („Ода Карађорђевићу”, „Мојој милој”), Антонија Р. Мајсторовића („Пјесна коју је сочинио и на дар поднео својим гостима на С. Климентија”), Исидора Стојановића („Поучителна изреченија, из Србијнаке)”, Алексе Чварковића („Мисли Србина”), Атанасија Николића („Пјесна”, „Радост радости”, „Са Авале вила”, „Подунавка”), Милоша Поповића („Нада бољи времена”, „Даворија”, „Ништа се не старајмо”, „Одзив српском духу” Милоша Светића (Јована Хаџића), песника под псеудонимом Милосава Слободина (Милош Поповић), Србољуба („Сербије Атлас").

Мојсеј Живојновић (1811-1865) учитељ, драмски писац и песник поздравио је победу уставобранитеља посебно штампаним стиховима под насловом: Срйска свеитковина йриликом йоврайка ГГ. Вучића и Пейронијевића у свое ойечестиво у Сербији држана, ${ }^{34}$ а у рукопису је остала његова песма као учитеља пожаревачког под насловом „Књаза Александра Карађорђевића 15. јунија 1843. године догодившег се", а посвећена је другом избору за кнеза:

Драга ми душо Срб-лозе роде!

Мајке у крилу пољупце примај!

Спокојне дане умешна рука

Ког' даде мени, наград то т' је!

Проником твојим, вандоглед продре

Да оружани гроза пакосни -

Природом сама, зато и груд ми

Награду т’ дати, диже се топло.

${ }^{33}$ Станиша Војиновић, „Два песника из времена Вучићеве буне”, Мещовийа ірађа Miscellanea, књ. XXXVI. Београд, Историјски институт, 2015, 147.

${ }^{34}$ Сочињено Мојс. Живојновићем. У Београду, у Типографији Књажества србског, 1844, $/ 2 /+6$ стр. $8^{\circ}$. 
Мутном на српском кој' хоризонту,

Буктиње палећ' образ показа

Истине праве, Срб-рода крви,

Жив буди свету то т' мајка жели.

Блаженом нек' т' је суштаства биће,

О српска крви! Стефана моћног.

Да! Постојанство пунити груди,

Надежду м' даје видит' Душмана -

Тврдој на стени темељ осниваш

Будуће дике српског посљедства.

Век Александру дај Метусала,

Мајка. О Боже! Љубимом жели... 35

Јован Илић (1823-1901) је као слушатељ прве године филозофије објавио песму „На дан миропомазанија његове светлости књаза српског Александра Карађорђевића, 26. октобра 1842. године", у класичном размеру, која почиње стиховима:

О сјајниј Фебе зрачног са Олимпа

У свити муза' притеци у помоћ, Да песму милу Српском уву, Лиру уз твоју појмо гласно,

$$
* \quad * \quad *
$$

Пресветлом дану, радости свеопште

Кад песме дивно свуда се разносе,

Умиљен Србин када руке

Весело к свевишњем Творцу диже. ${ }^{36}$

Као ученик хвалио је Александра, а када је истеран са Лицеја 1844. постао је приврженик династије Обреновића. Занимљив је и због става, у поезији, пошто је међу првима устао против удварања турским великодостојницима и султану. Активно је учествовао у свргавању Александра Карађорђевића и подржао долазак династије Обреновића 1858. године. У својим песмама користио је народну поезију, лексику и теме истока и по томе био познат у књижевним историјама.

Влаяислав Сӣојаgиновић (1806-1844) је прво певао кнезу Милошу, а када се променила власт, као државни чиновник, испевао је Александру Карађорђевићу „Оду његовој светлости, милостивјејшем господару и књазу српском Александру Карађорђевићу на дан миропомазања његова, 26. октобра 1842. год., на књажеско достоинство". Као класицистички песник он је за мото узео стихове Мушицког и поздравио новога књаза:

35 Архив Србије, МУД-П, 1843, IV, 144.

36 Дояайак к Срйским новинама, 1842, бр. 45 (7. новембар), 183. Прештампано: Голубица за 1842, Београд, /1842/, 143-145. Песма се не налази у Целокуйним gелима Јована Илића, која је приредио Јаша М. Продановић. Београд, Библиотека српских писаца /1928-1931/. 
Чуј свете радост! чуј нечувено свим

Правим весеље Србима! Млад и стар

(Деца на сиси мајке нежне)

Сунце поздрављају јарко данас. ${ }^{37}$

Међу песницима се налазе непотписани аутори или под различитим псеудонимима.

Неке псеудониме нисмо успели да разрешимо. Међу њима је најпознатији обреновићевац Доброслав Паливоља, који је у Новом Саду објавио стихове под насловом Пјесма нарояна о сйану Србије йосле несрећной йоgиїну-

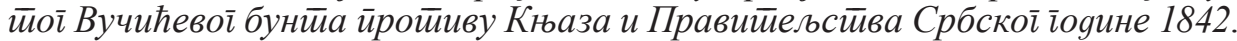

Песник је показао изузетну ученост, стављајући, као мото својим стиховима, мисли Виланда и Коцебуа („Буна је приљепчива као куга”) на немачком језику и у преводу. Писана је по угледу на народни десетерац а почиње стиховима:

Мили Боже чуда големога!

Што се Ртањ у по' ноћи свјетли

А по њему вију облачине?

Што се чују из дубљине гласи

Као из даље туче тутњавина?

Вила обилази Србију и налази само зулуме Вучића и његових присталица, па призива кнеза Михаила да је избави из беде. Посебно истиче војни сукоб кнеза Михаила и Вучићеваца, када:

Тек’ погибе Адрејевић Арсо

Од Богдана да га Бог убије!

Тек Миленко свисну Капетане,

Понос, дика својих родитеља

Та Милете Радојковић Старца

Што у боју остарио љутом

А бранећи своје отечество;

Тако неста Поповића Ђорђа,

Маџаревић Димитрија с њиме,

Са многима сивим соколовма. ${ }^{38}$

Други писац, Крагује Дивостињац, објавио је песму до које нисмо успели да дођемо, под насловом Поиев сажаљени. Збрао йоg Транабасом на Мейином бряу слущиавии йлач Гружанке девојке (Нови Сад 1843).

Трећи аутор, који је непотписан, објавио је посебно песму Плач срйске виле збої gоїађаја у Србији 1842, која има 1320 углавном десетерачких стихова, штампана је предвуковском азбуком. Почиње стиховима који стилски подсећају на стихове Симе Милутиновића (из Србијанке):

37 Додатак к Срйским новинама, 1842, 48 (28. XI), 195.

${ }^{38}$ Нови Сад, Писмени Кат̄арине Јанковић Уgове, 1843, 14 стр. 
Мелпомено, сиња кукавицо, Од' помози жалосној ми тужит'!

И ви миле бједне моје друге

Све које сте мен' изгледале,

Стеците се помоз' те ми плакат',

Сузе лити и тужит' чемерно,

Изјадат' се јер не могу сама;

Смрт Душана премилог ми сина,

Нит Курварство Клета Вукашина,

Смрт Милоша, ил' издајство Вука,

Нит несрећна Лазарева битка

А онда прелази на Вучићево издајство

Вук опет нам Вучића оставља

Не гледајућ' колико је крви

Сонародне проливено зато,

Он из петњи да се упне жила,

Сваку распру и неслогу клету,

Међу родну сипајући браћу,

Утаманит' он да на вјек гледа,

Даноноћна то да м' буде брига.

И он Вјерни свога предка слуга,

Усрећено Оточество своје

Самамоћу и крвавим трудом,

Већ до славе браћом доведено,

Обдарено са надеждом сјајном

Мијајлом Владатељем милим

Тако је Вучић лажући народ „Народ дизо противнике сјеко”. А придружиле су му се издајице: начелник Јовица, Спасо Смедеревац, Книћанин, капетан Риста, Милосав Ресавац, Богдан Ђорђевић Параћински, начелник Пера, Паун Јанковић, Прота Матија Ненадовић, Лазо Теодоровић, а за то време „Аврам сједи при Кољену Паше”.

Када је кнез Михаило чуо да је Вучић прешао Дунав код Смедерева шаље своје људе у народ: Катића у Пожаревац, Арсу, „друму за Коларе”, Милутина у Крагујевац, Лазу Брку у београдску нахију, Браљинца у Крушевац, Милоша Богићевића у Подриње, Шабац и Ваљево, своме стрицу Јовану Обреновићу.

Вучић се приближио Крагујевцу, лажима је придобио војнике и задобио град. Када је кнез Михаило са војском дошао већ је било касно, Вучић је испалио из топова,

Са своима стријељати стаде,

С друге опет с тешкијем картачом, 
Бунтовничка ста обарат страна

Бјежи јадна без обзира свака,

Кнез не желећи да се пролива братска крв повукао се према Београду и прешао у Земун. ${ }^{39}$

Непознати под словом Н. (могао би бити Атанасије Николић) објавио је сонет У славу Њеїове Свјейлосиии Алексаняра Карађорђевића Србије Књаза:

Самовољност гди с' гњездила грозна, Гдје слобода трта бје с правдом:

Ту веселим гледам сада оком

Србски живот, - поља пуноросна.

Слава рече. У том мајка мила

На Врачару спази јуначком

Скуп у руву људства војачком;

Ближе сматра; - с радосћу ј' узрила:

Од Авале гдје Србске витези Холост ништећ' - гласа дижу клик:

„Круно владе Алексаняра реси”-

Србске среће мили данци свићу! Над Себијом неба бдије лик! -

Живот, здравље Карађорђевићу! 40

Група анонимних песника је прилична, јер су многи у зависности коме припадају желели да покажу своју приврженост једној или другој династији. Највећи део анонимних стихова били су намењени најширој читалачкој публици, и сачувани су у рукописима. Њих је полиција сакупљала, а некада, ако се сазнало ко је аутор и ислеђивала кривца (на пример Станоја Ћосића и др.)

У исто време појавио се и један број анонимних штампаних стихова у београдској штампарији или штампаријама на граници, у Земуну, Сремским Карловцима, Новом Саду, али и песама штампаних у листовима, које нису непотписане.

Међу првима је песма непознатога, којом се испраћају уставобранитељи у изгнанство, под насловом „Београђанин на Каија Бурну [Карабурми!] 17-ог октомврија 1840", а има стихове:

То су блага ранитељи

То је славе наше пук!

То Устава бранитељи!

То пернати стрела лук!

${ }^{39}$ Нови Сад 1843. 47 стр.

40 Буяимско-иемейански скоройеча, 1842, I, 39 (12. XI), 237. 
А онај, онај на брегу

Што остаде, плачниј рој,

Као јагањци на снегу,

Оно им је род и сој.

Они одоше, а царскиј

Посланик и Комесар

Њи испраћа господарски

Почести и љубве жар.

Они одоше и с њима

Залази нам сунца свет;

Сербију окова зима,

Љубкиј кида на њој цвет. ${ }^{41}$

У Београдској типографији штампани су, често анонимно, разни поздрави „народа”, кнезу Александру, Томи Вучићу Перишићу и другима. Тако је 1844. године објављен „Поздрав народа српског премилим своим старешинам' господи Вучићу и Петронијевићу приликом повратка у Србију месеца августа 1844.” (4 стр), а који подсећа на сличан поздрав кнезу Милошу девет година раније, такође анонимног аутора: „Поздравље коим је србскиј народ светлог књаза и господара свог Милоша Теодоровића Обреновића I повративши се из Цариграда у месецу ноемврију 1835. лета свеусрдно дочекао” (Београд, 1835, 4 стр.)

Такав је, по структури класичан, по садржају удворички „Поздрав светлом књазу српском Александру Карађорђевићу". 42

До наших дана сачувало се и неколико песама, које су тајно распростиране преписивањем и достављане грађанима Београда, Шапца и других места у Србији. Међу таквим песмама налази се и песма непознатог аутора, писана мешавином грађанске и црквене ћирилице. Заплењена је и предата полицији. Она почиње молбом и поздравом, „Љубезнаја Браћо искрени пријатељи и сладчајши соотечественици рода Српског Здравствујте”:

Помоћ дајте наследственом Књазу,

по имену младом Михаилу,

ког смо једва међ нас дочекали

с раширени руку к себи прегрлили,

Зашт злотвори старог нам прегнаше,

и народу криво се заклеше,

да воледу његовога сина,

по имену умершег Милана

којег одма за њим отроваше.

${ }^{41}$ Срйски наровни лист̄, 1841, VI, 3 (19. I), 17.

42 Дояайак к Срйским новинама, 1842, 44, (31. X), 179-180. 
а завршава се молбом: „О! многоименити владико, и всего добра датељу, теловјекољубче царју и господи јешч и у Бога јесам и аз дерзају призивати чудноје, страшноје, и свајатое имја твоје, а не мерско ти буди моление сие, јешче глагољу пред тобоју, помилуј бо лаговернаго, державнаго, и многовозљубленог Књаза Михаила нашего, веруј ему всшчедри Создатељу долгољетное здравје, да вес грешни род Србие твој с радостију воскликнет, и тебе господа и Бога нашего во вјеки восхвалит". 43

\section{НАРОДНЕ ПЕСМЕ}

Познато је, а то горе помиње и Јован Хаџић, да је народ за време ових догађаја певао народне песме. Једна од песама такве врсте, једна од ређих, објављена је и у листу Пояунавка. То је „Српска народна песма. (Из најновијег времена)", са стиховима:

Полетише двије птице вране,

Из Трнаве села поносита, Са Чумића поља широкога, Преко гора и преко дубрава, И планине више Јагодине.

Двије птице ту се сувратише, Јагодину шејер поздравише, Верном друштву абар учинише, Јеремији писмо предадоше, Јербо глава Јагодини беше, И начелник целог окружија. ${ }^{44}$

У овој песми су опеване тада савремене личности, и биле предмет полемике и тужбе Правитељству од стране поменутих у њој: Јеремије Станојевића и Богдана Ђорђевића. Изјаве о дозволи за њено штампање дали су цензор Василије Лазић, уредник Милош Поповић, Јован Стерија Поповић и Сима Милутиновић. После дуже преписке, изјаве Милоша Поповића да је песму цензурисао Јован Стерија Поповић изјаснио се и Сима Милутиновић (Београд 2. новембар 1845), да је Народна пјесна, печатана у Поgунавки, која се односи на Капетана Богдана, и у којој се Г. Јеремија Станојевић спомиње, у време врачарске Скупштине, мени у логору онде од некога дата, да је у Новине ставим, и ја сам је учреднику још онда предао, који ми је рекао, да заонда је не може штампати, јер има млого други прилога, него да ће он то с временом учинити". Из даљег ислеђења види се да није доказано да је песма предата уреднику Пояунавке после Врачарске скупштине, него можда много касније, а изгледа да је Милутиновић штитио Стерију, или је сам аутор „тобожње” народне песме.

43 Архив Србије, МИД-В, 1840, I, 134.

44 Пояунавка, 1845, III, 41 (13. X), 171-172. Прештампана је у књизи: Милорад Радевић - Миодраг Матицки, Нароgне йесме у срйској иеериоgици go 1864, Нови Сад - Београд 2007, 131-133. 
Уставобранитељска поезија временом се преобратила у династичку, а доцније у удворичку поезију.

У реакцији на поезију уставобранитеља био је став српских песника, да је доста писања похвала султану и представницима династија. Поезија мора да буде оно што јесте, независна од власти, што се нарочито види у безбројним антологијама стихова о Карађорђу, Милошу и Карађорђевићима.

У Ант̄олоіији срйске уgворичке йоезије Маринка Арсића Ивкова налазе се и три песника из времена уставобранитеља. Две песме су Милутиновићеве: „Честитање Крбан'-бајрама Муса паши 1841” и „Разговор два Србина”, а по једна од Јована Стерије Поповића: „Отечествена песма најрадостнијем у Сербији дану имена његове светлости срећно владајућег господара и књаза српског Михајла М. Обреновића" (песма је певана, а мелодију је компоновао Јосиф Шлезингер) и Јована Хаџића „Књазу србском Александру Карађорђевићу". 45

Судбине ових удворичких песника су исто тако занимљиве. Милутиновић је пред крај живота тражио да се осуде злодела великаша, а после његове смрти је кружила прича да је отрован у „Оџаклији Зубановој”. Стерија је после одласка из Србије у Вршац, а згађен злочинима у Катанској буни, написао песму „Злочинац” (Сеgмица, 1856) са стиховима о Томи Вучићу Перишићу:

Гле како болан на постељи јечи

Некад беснивши ка̂но тигар звер,

Пакленим гласом зла му совест звечи

И муку двојну трпи крвождер.

Сад се тек душе појављују редом,

Горко страдавше од једа му злог,

Свак својом клетвом, сваки својом бедом

Трзајућ’ совест мужа пакленог.

Напад на поезију уставобранитеља уследио је после промене Александра Карађорђевића династијом Обреновићима, другом владом кнеза Милоша и Михаила. Уследио је у књижевности нападом на Банову „Оду султану”, када су готово здушно скоро сви устали против оваквог песништва. Задржало се нешто друго што је важније, певање истоку и источњачком, али ће и оно престати смрћу Јована Илића, иако се још понегде могло осећати у стваралаштву његових синова Војислава и Драгутина.

45 Београд 1988, 23-31. 
ORIGINAL SCIENTIFIC PAPER

STANIŠA VOJINOVIĆ

Belgrade, Serbia

E-mail: stanisavojinovic@eunet.rs

\section{DEFENDERS OF THE CONSTITUTION AND POETRY}

SUMMARY: The paper analyzes the poetry of the defenders of the Constitution and their opponents, which represents the beginning of multi-party life in Serbia and the beginning of political (dynastic) poetry. Three poets, Sima Milutinović, Jovan Hadžić and Đorđe Grozdanović, were especially highlighted, and some forgotten ones were also mentioned, such as Đorđe Maletić, Tatomir Milovuk and others.

KEYWORDS: dynastic struggles, Sima Milutinović, Jovan Hadžić, Toma Vučić Perišić, Avram Petronijević, Turkey, poets, courtship 